\title{
SISTEM PELAYANAN APOTIK ONLINE BERBASIS WEB
}

\author{
Roro Santi \\ Politeknik LP3I \\ e-mail : rorosanti@plb.ac.id
}

\begin{abstract}
Abstrak : Semua komputer yang terhubung dengan internet dapat bertukar informasi melalui World Wide Web (WWW), yang menerapkan hubungan melalui hypertext link. World Wide Web (WWW) adalah arsitektur kerja dalam mengakses dokumen-dokumen yang tersebar pada ribuan mesin di internet. Pada dasarnya, web merupakan sistem clientserver yang berguna untuk melakukan pencarian dan mengakses berbagai informasi di internet dengan sangat mudah, hal ini menjadikan web sebagai salah satu media informasi bagi setiap orang dari berbagai kalangan. Selain itu penyediaan informasi, layanan atau produk yang disiapkan secara elektronis oleh pihak intern perusahaan atau instansi tertentu, tidak terbatas tempat dan waktu, yang menawarkan nilai lebih untuk partisipasi pada semua kalangan. Berkaitan dengan informasi dan pelayanan, apotik merupakan salah satu sarana kebutuhan masyarakat yang menyediakan berbagai macam kebutuhan obat yang tentunya sangat dekat dengan bidang medis atau kesehatan. Pelayanan akses online yang merupakan sistem jaringan penghubung masyarakat tanpa mengenal jarak untuk bidang medis, juga menjadi kebutuhan masyarakat khususnya pengguna internet.
\end{abstract}

Kata Kunci : Web, Informasi, Layanan, Apotik, Online.

\section{Pendahuluan}

Semakin meningkatnya ragam produk-produk elekronik sampai menjalar ke dunia internet. Seperti e-commerce, e-learning, e-government, dan tidak ketinggalan juga ehealth. Hal ini membuktikan bahwa teknologi informasi dan komunikasi semakin berkembang. Sebagai jaringan komputer global, pada saat ini internet banyak digunakan oleh berbagai kalangan. Semakin banyak pemanfaatan internet, dikarenakan para penggunanya memerlukan sebuah informasi tertentu.

Semua komputer yang terhubung dengan internet dapat bertukar informasi melalui World Wide Web (WWW), yang menerapkan hubungan melalui hypertext link. World Wide Web (WWW) adalah arsitektur kerja dalam mengakses dokumen-dokumen yang tersebar pada ribuan mesin di internet.

Pada dasarnya, web adalah sistem client-server. Dari sisi pengguna (client) web merupakan kumpulan dokumen-dokumen yang tersebar di mesin-mesin di internet yang berisi data teks, gambar, gambar bergerak ataupun suara. Sedangkan dari sisi server web mendengarkan permintaan dari mesin client melalui sebuah koneksi yang melakukan permintaan (request) dan server mengirimkan balasan permintaan (replies) yang ditampilkan pada sebuah browser [1].

Mencari dan mengakses berbagai informasi di internet menjadi sangat mudah. Hal ini menjadikan web sebagai salah satu media informasi bagi setiap orang dari berbagai kalangan. Sehingga tidak menutup kemungkinan setiap perusahaan atau instansi tertentu, saling berlomba memamerkan profil mereka dalam sebuah website. Selain itu penyediaan 
informasi, layanan atau produk yang disiapkan secara elektronis oleh pihak intern perusahaan atau instansi tertentu, tidak terbatas tempat dan waktu, yang menawarkan nilai lebih untuk partisipasi pada semua kalangan.

Berkaitan dengan informasi dan pelayanan, apotik merupakan salah satu sarana kebutuhan masyarakat yang menyediakan berbagai macam kebutuhan obat yang tentunya sangat dekat dengan bidang medis atau kesehatan. Pelayanan akses online di bidang medis, juga menjadi kebutuhan masyarakat khususnya pengguna internet. Tentu saja hal ini menuntut kualitas pelayanan apotik untuk selalu siap bicara (menyediakan akses layanan kepada publik), mendengar (menerima input dari publik untuk memberikan informasi atau keputusan) dan meningkatkan layanan publik (berdimensi sekitar stok obat, informasi obat ataupun seputar harga obat).

Ada dua manfaat langsung yang dapat diambil dari penggunaan teknologi informasi dan komunikasi ini. Pertama untuk pihak internal, yaitu menyediakan manfaat yang lebih baik untuk selalu memotivasi pelayanan atau staf pelaku pelayanan dalam bekerja dan kontrol yang baik untuk selalu memperbaiki citra di publik. Kedua untuk pihak eksternal, yaitu penyampaian yang cepat dan mudah menyebabkan pelayanan yang baik ini dapat dinikmati oleh populasi yang luas [2].

Berdasarkan kebutuhan inilah, penulis tertarik untuk membangun sebuah prototype sistem pelayanan apotik secara online berbasis web. Sehingga memungkinkan untuk memberikan pelayanan melalui internet.

\section{Bahan dan Metode}

Metode penelitian dilakukan dengan cara analisis, yaitu metode yang berusaha mengumpulkan, menyajikan serta menganalisis data sehingga memberikan gambaran yang cukup jelas mengenai permasalahan yang ada. Teknik pelaksanaannya, adalah sebagai berikut :

a. Survey, yaitu mendatangi beberapa lokasi apotik untuk mendapatkan gambaran sistem dari data yang diberikan, melalui wawancara dengan pihak yang berwenang, brosur ataupun pamplet sehingga dapat dilakukan analisis terhadap sistem.

b. Studi Pustaka, yaitu pencarian literatur teori dari berbagai referensi baik itu internet, buku, majalah dan laporan-laporan.

c. Tahap analisis dan perancangan menggunakan metodologi yang berorientasi pada aliran data.

Menurut kamus umum bahasa Indonesia, apotik berarti rumah obat. Sedangkan menurut arti bahasa merupakan tempat menjual segala jenis obat untuk keperluan masyarakat luas. Sebelum berlakunya Peraturan Pemerintahan nomor 25 tahun 1980, setiap orang boleh meminta izin untuk membuka sebuah apotik. Asalkan berbentuk suatu badan hukum, P.T. atau C.V. Pimpinannya juga tidak mempelajari manajemen, dengan modal utamanya hanya satu, berjiwa dagang. Pengetahuan tentang teknik farmasi, apalagi tentang peraturan perundang-undangan farmasi mereka banyak yang tidak mau tahu, sehingga tidak jarang sering terjadi pelanggaran-pelanggaran. 
Dengan berlakunya PP-25/1980 yang hanya membolehkan izin diberikan kepada seorang apoteker untuk mendirikan usaha membuka sebuah apotik, maka pemerintah mengharapkan hal-hal yang tidak baik seperti adanya pelanggaran-pelanggaran sebelum

berlakunya PP-25/1980 tidak terjadi. Apabila hal tersebut terjadi, maka pemerintah melalui Dirjen POM, yaitu Balai POM (Pengawas Obat dan Makanan) setempat dapat dengan mudah menegur si-apoteker yang melakukan pelanggaran tersebut, bahkan surat izin kerja-nya dapat dicabut apabila si-apoteker masih terus membandel. Maka dengan berlakunya PP-25/1980, kedudukan apoteker dikembalikan pada posisi yang sebenarnya di apotik, yaitu sebagai tempat pengabdian profesi.

Sampai kini peranan apotik sebagai rumah obat masih tercampur dengan unsur dagang, atau untuk mencari keuntungan. Maka tak heran apabila seorang apoteker ingin membuka usaha apotik, ia haruslah mengerti minimal tentang cara-cara berdagang dengan memperhitungkan segala konsekuensi, tetapi masih banyak juga para Apoteker Pengelola Apotik (APA) yang tidak berjiwa dagang, yang tidak atau kurang, atau belum berpengalaman membuka sebuah usaha, sehingga menjadi takut, frustasi, atau apatis.

Peranan Apoteker Pengelola Apotik (APA) di apotik yang terpenting adalah sebagai informan obat kepada masyarakat dan segala sesuatu yang ingin diketahuinya. Oleh karena itu para APA harus mampu menguasai segala macam pengetahuan tentang semua jenis obat-obatan. Dengan memberikan informasi kepada pasien, diharapkan dapat terjadi hubungan baik antara petugas apotik dengan pasien, sehingga dapat menghindarkan kemungkinan terjadinya kesalahan dalam penyerahan obat. Kesalahan tersebut bisa terjadi disebabkan oleh karena petugas apotik kurang komunikatif dengan pasien atau pembeli.

Maju atau mundurnya suatu apotik juga dipengaruhi oleh lokasi apotik itu berada. Oleh karena itu sebaiknya letak apotik berada di daerah yang ramai, daerah yang aman, daerah yang dekat rumah sakit atau klinik, daerah yang disekitarnya terdapat beberapa dokter yang praktek, daerah yang strategis, mudah dijangkau, atau mudah dan sering dilalui oleh kendaraan, serta daerah yang cukup banyak penduduknya. Memilih lokasi apotik di kotakota yang sudah banyak apotiknya tidak boleh semau kita, tetapi harus memenuhi persyaratan jarak minimal antar apotik-apotik.

Selain harus memenuhi persyaratan jarak minimal antar apotik, apoteker pengelola calon apotik harus menghubungi kantor wilayah Departemen Kesehatan Propinsi untuk dapat mengetahui wilayah lokasi yang masih diperkenankan untuk pendirian dan atau perpindahan apotik. Daftar wilayah lokasi tersebut secara periodik dituangkan dalam surat keputusan Menteri Kesehatan RI dalam lampirannya yang ditandatangani oleh Dirjen POM atas rekomendasi kantor Wilayah Departemen Kesehatan RI masing-masing propinsi [3].

Tugas dan fungsi apotik berdasarkan PP RI No. 25 Tahun 1980, yaitu [4]:

a. Tempat pengabdian profesi seorang apoteker yang telah mengucapkan sumpah jabatannya.

b. Sarana farmasi yang melaksanakan peracikan, pengubahan bentuk pencampuran dan penyerahan obat atau bahan obat.

c. Sarana penyalur perbekalan farmasi yang harus menyebarkan obat yang diperlukan masyarakat secara meluas dan merata. 
Untuk membangun suatu aplikasi perangkat lunak berbasis web, maka diperlukan suatu model yang yang akan dijelaskan pada gambar di bawah ini.

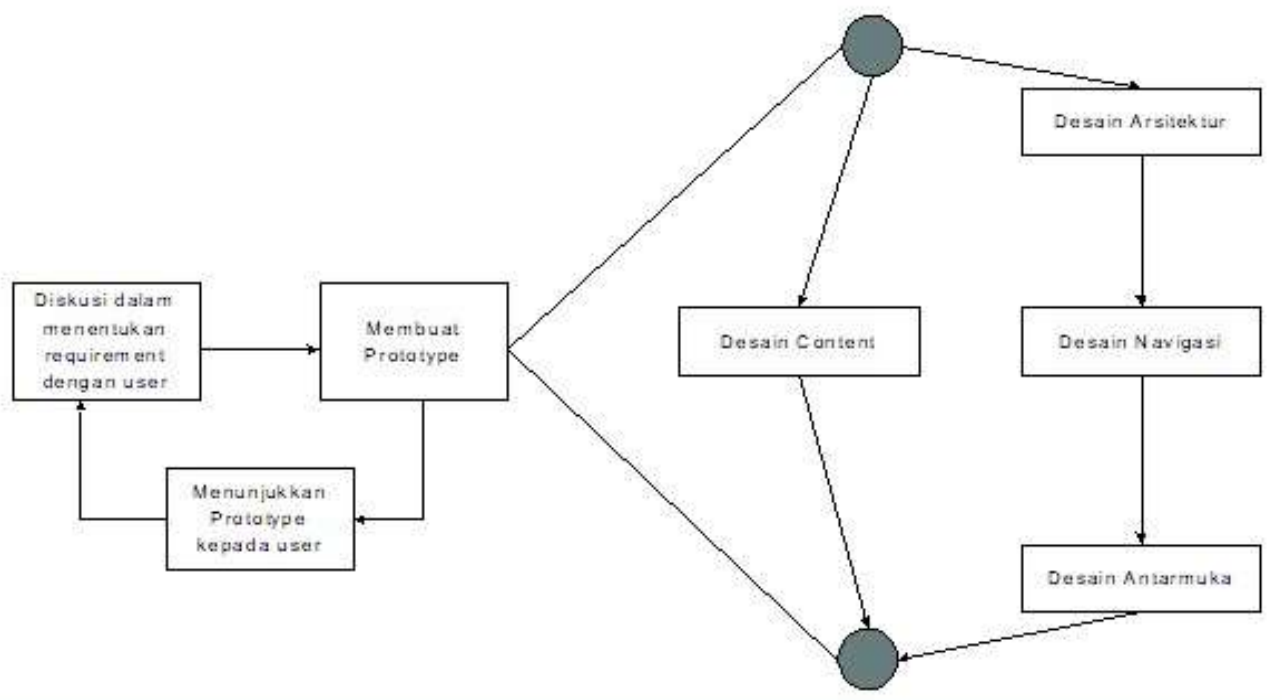

Gambar 1.

Model Proses Pembangunan Perangkat Lunak Berbasis Web [5].

Desain content, bertujuan agar informasi yang ditampilkan tepat sasaran. Desain arsitektur dan navigasi, bertujuan untuk mengidentifikasi jalan akses terhadap isi web. Dibawah ini adalah gambar struktur jaringan atau web murni.

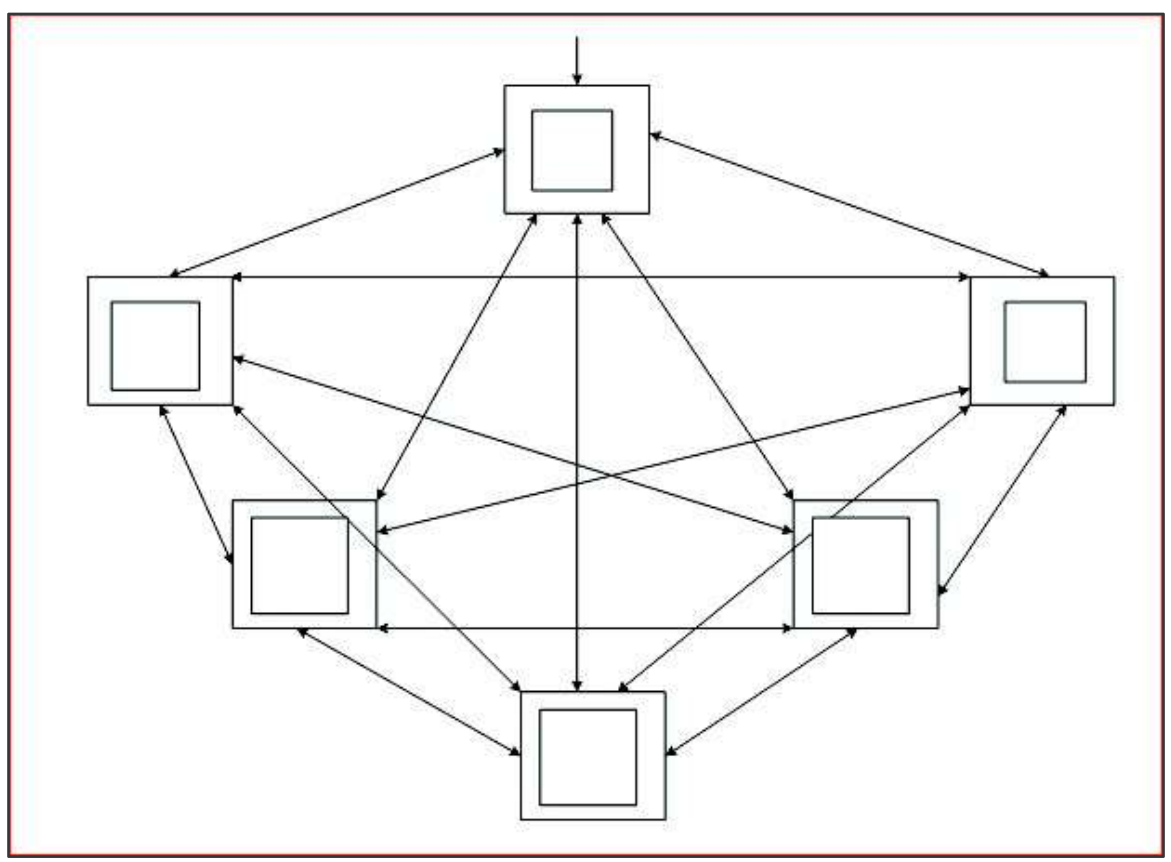

Gambar 2. Struktur Jaringan atau Web Murni [PRE01]. 
Pada struktur ini kita dapat me-link dari halaman satu menuju halaman yang lain dari struktur. Struktur ini menjadikan penggunaan navigasi menjadi fleksibel.

\section{Hasil dan Pembahasan}

Setelah melakukan riset awal melalui penelitian sebelumnya. Selanjutnya adalah tahap analisis. Yaitu suatu tahap pemahaman proses, yang bertujuan untuk mengetahui proses apa saja yang akan ada di dalam sistem, bagaimana kerja dari setiap proses yang terlibat di dalam sistem, dan hubungan satu proses dengan proses lainnya.

Dari pemahaman proses tersebut, maka dapat dilakukan suatu evaluasi dan usulan terhadap sistem perangkat lunak yang akan dirancang. Dengan demikian dapat dikatakan bahwa tahap analisis ini merupakan tahap analisa kebutuhan, yang akan digunakan untuk tahap perancangan prototype web.

Tahapan uraian materi pada bab ini, meliputi analisa sistem yang dirancang berdasarkan hasil survey di beberapa apotik bandung dan beberapa apotik online di internet. Untuk lebih jelasnya hasil survey dapat dilihat pada lampiran. Setelah analisa sistem tersebut, yaitu sistem yang menjadi sistem manualnya pelayanan apotik online. Kemudian diuraikan analisa kebutuhan perangkat lunak, dari sistem perangkat lunak yang dirancang.

Berikut adalah asumsi dan batasan sistem pelayanan apotik online :

a. Pemesanan obat melalui internet, diberikan kepada konsumen yang telah terdaftar sebagai anggota. Dan anggota ini adalah seorang pelanggan yang telah melakukan konfirmasi dengan pihak apotik melalui proses pendaftaran anggota.

b. Layanan informasi adalah tentang obat dan seputar kesehatan obat meliputi jenis kemasan, khasiat, dosis penggunaan, efek penggunaan, stok, dan harga obat. Layanan ini diberikan kepada semua konsumen yang membutuhkan informasi obat. Informasi seputar kesehatan, meliputi informasi rumah sakit, dokter, apotik, artikel kesehatan dan tips kesehatan. Layanan ini diberikan kepada semua konsumen yang membutuhkan informasi tersebut.

Prosedur kerja pada sistem pelayanan apotik online, yaitu yang terdiri dari beberapa prosedur meliputi :

a. Pendaftaran anggota

Yaitu prosedur yang melakukan proses-proses pendaftaran anggota, meliputi :

1) Pengecekan data keanggotaan.

2) Konfirmasi keanggotaan.

b. Pemesanan obat

Yaitu prosedur yang melakukan proses-proses pemesanan obat, meliputi :

1) Pengecekan data anggota.

2) Pengecekan data pesanan.

3) Konfirmasi pesanan.

4) Pencetakan data pesanan.

c. Pelayanan informasi

Yaitu prosedur yang melakukan proses-proses layanan informasi, meliputi :

1) Pencarian informasi. 
2) Pemberian informasi.

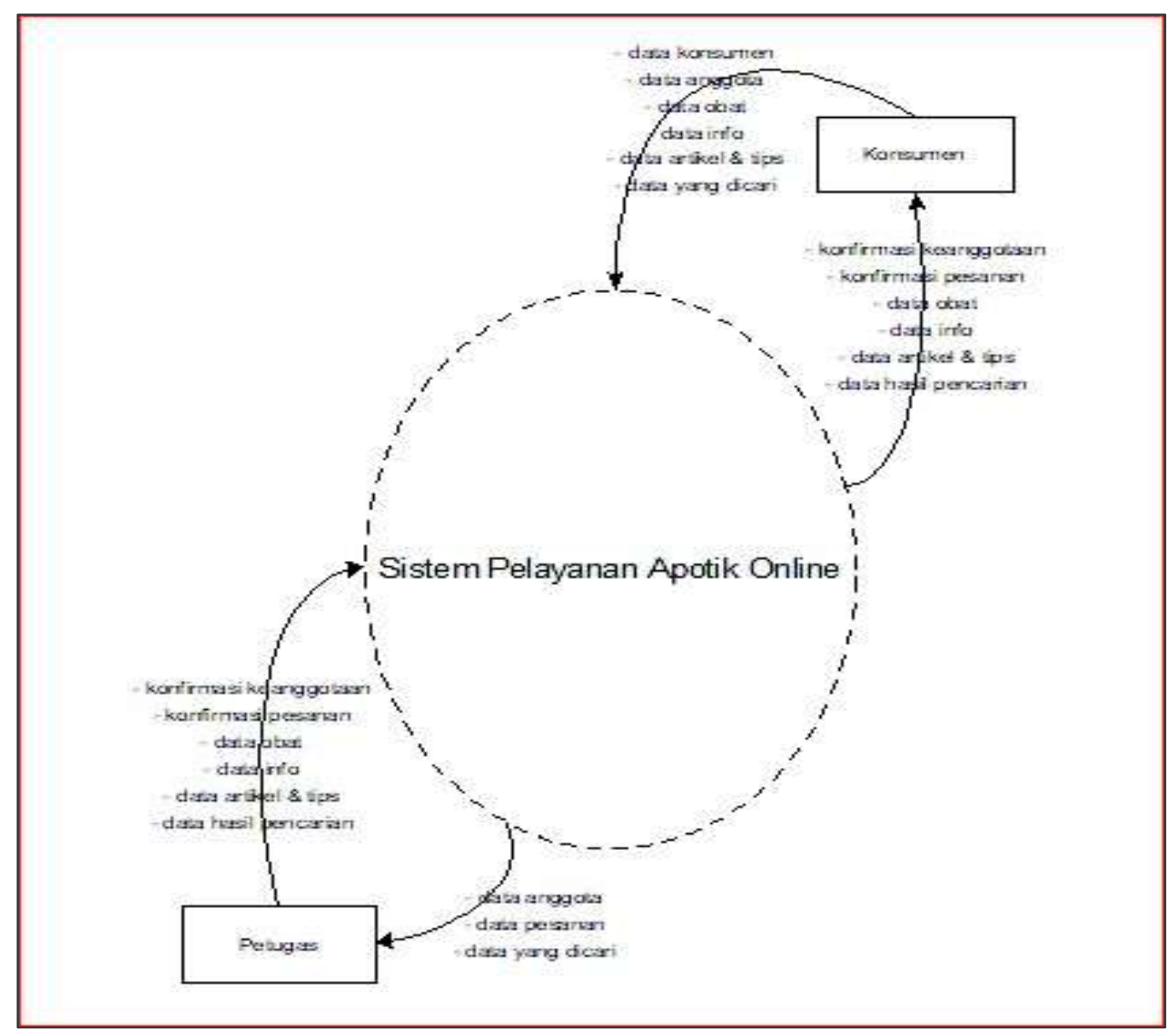

Gambar 3. Diagram Konteks (Analisis Sistem).

Berdasarkan analisis sistem diatas dan laporan hasil survey, disimpulkan bahwa sistem pelayanan apotik secara online, merupakan sistem yang memberikan pelayanan kepada konsumen melalui media internet, telepon atau media lainnya. Sehingga konsumen selain dapat mengunjungi langsung lokasi apotik, atau dapat melakukan pembelian obat dan pemesanan obat melalui internet, telepon dan lainnya. Hal ini memberikan kemudahan kepada konsumen untuk menghubungi apotik. Dan memberikan banyak peluang kepada pihak apotik untuk memperluas konsumen, terutama melalui internet.

Setelah perancangan membangun prototype web, untuk sistem pelayanan apotik secara online yang merupakan tahap paling utama dari penelitian ini. Selanjutnya Perancangan struktur link yaitu mendesain link navigasi, pada setiap halaman dengan metode web terpusat, pada satu halaman utama yaitu homepage. Untuk lebih jelasnya dapat dilihat pada gambar 7. 


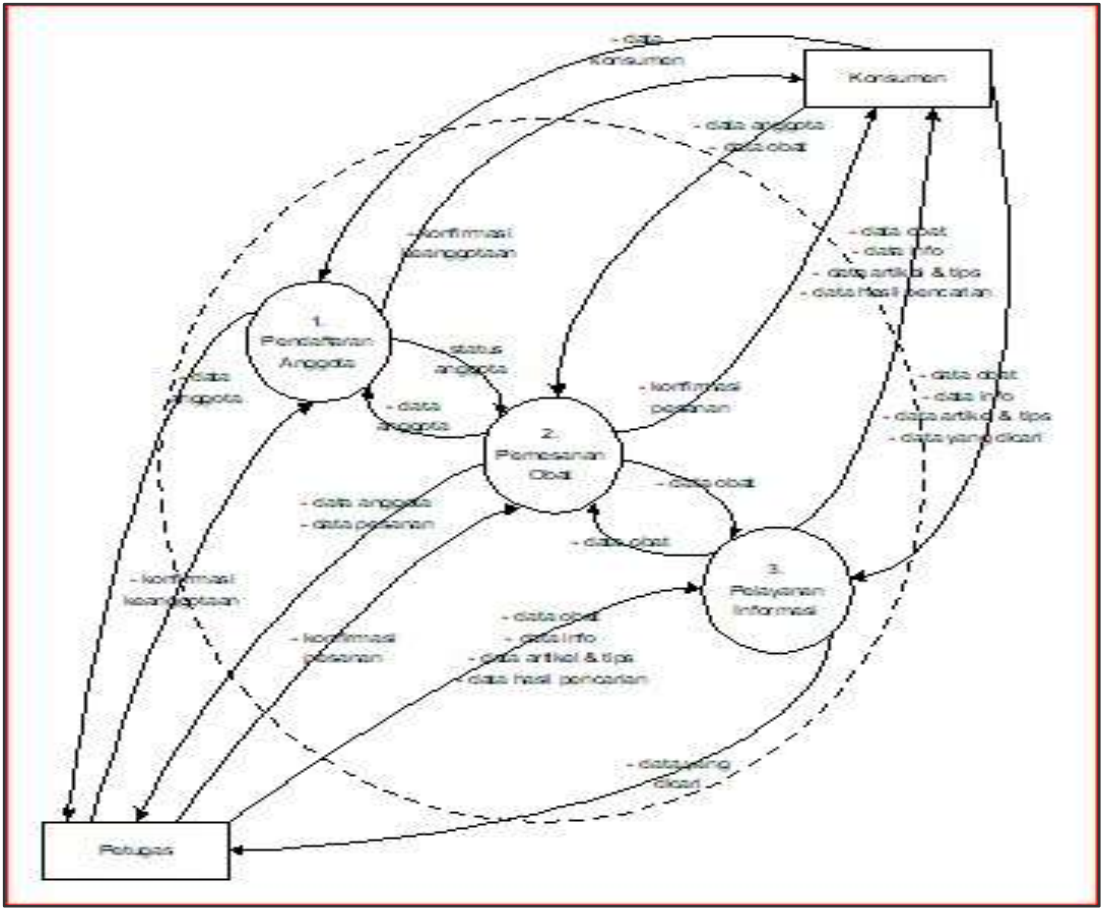

Gambar 4. DFD Level 0 (Analisis Sistem).

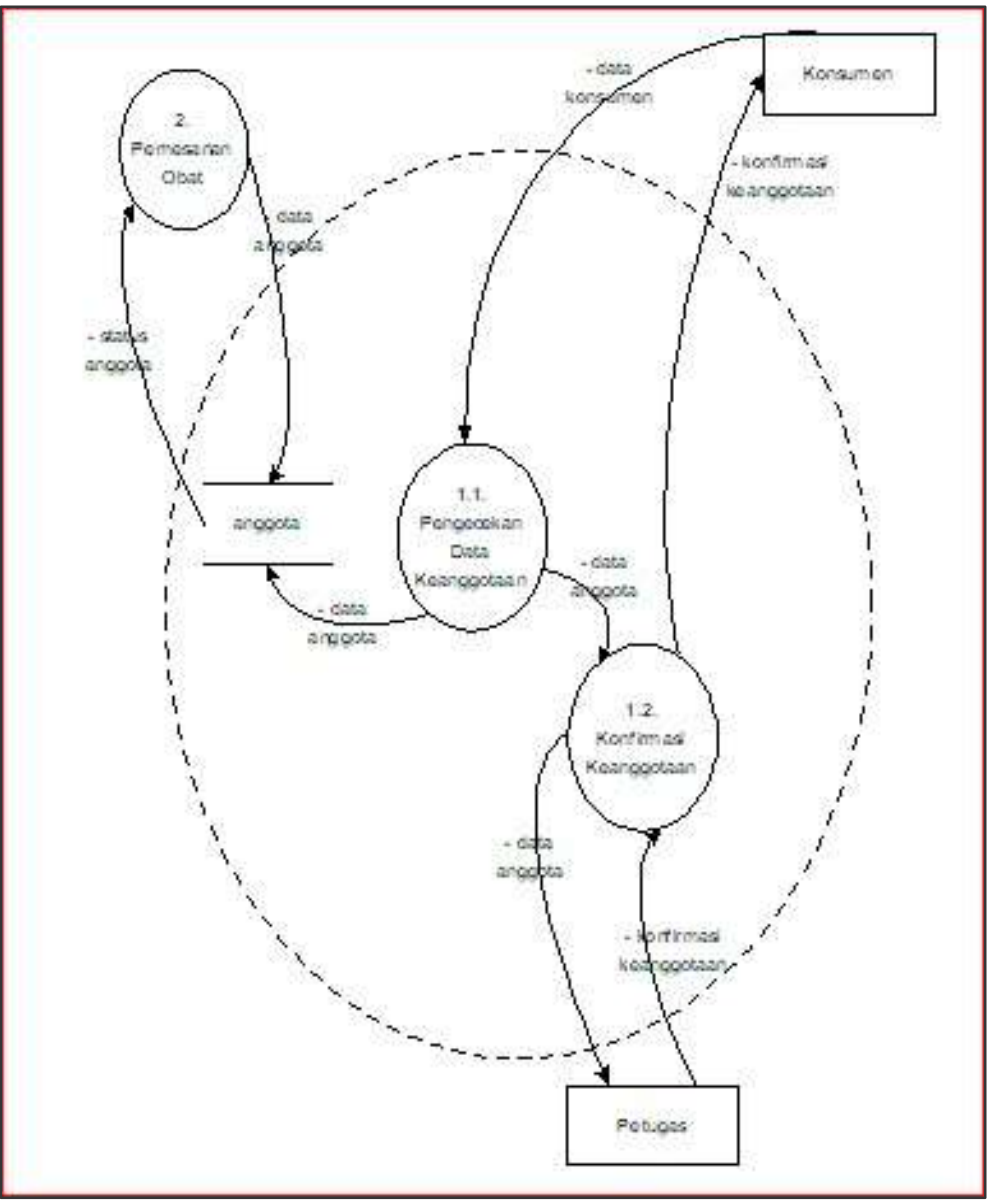


Gambar 4. DFD Level 1 Prosedur Pendaftaran Anggota (Analisis Sistem).

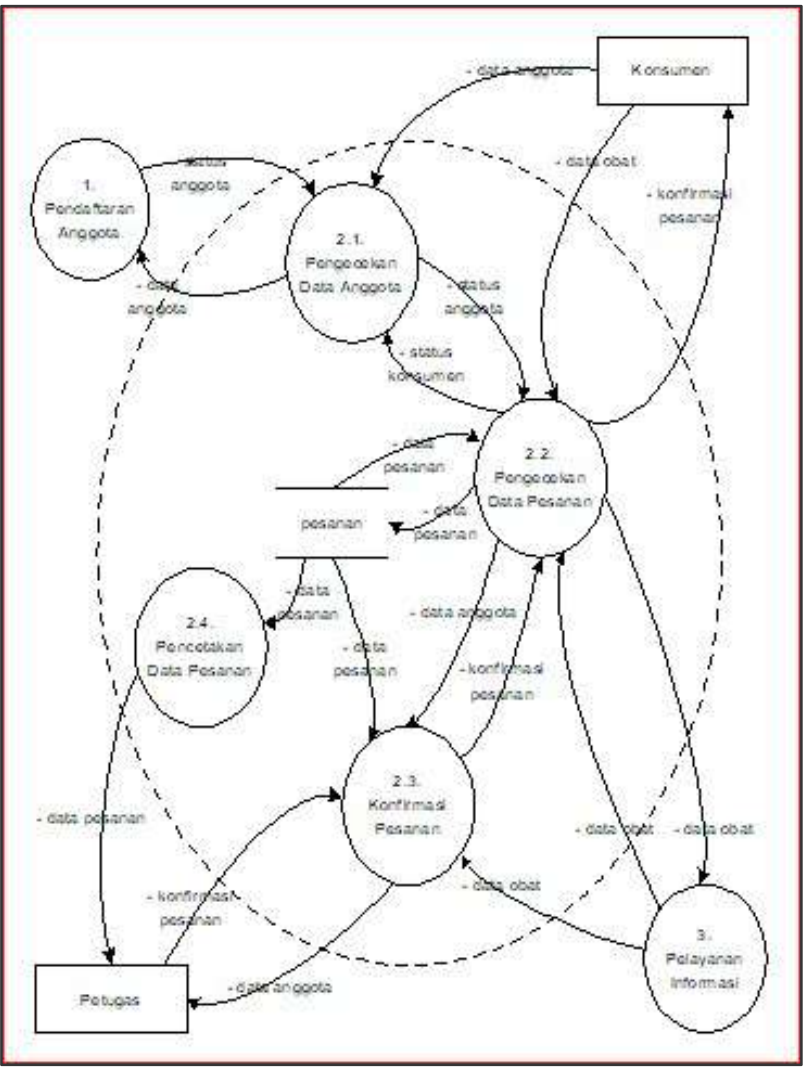

Gambar 5. DFD Level 1 Prosedur Pemesanan Obat (Analisis Sistem).

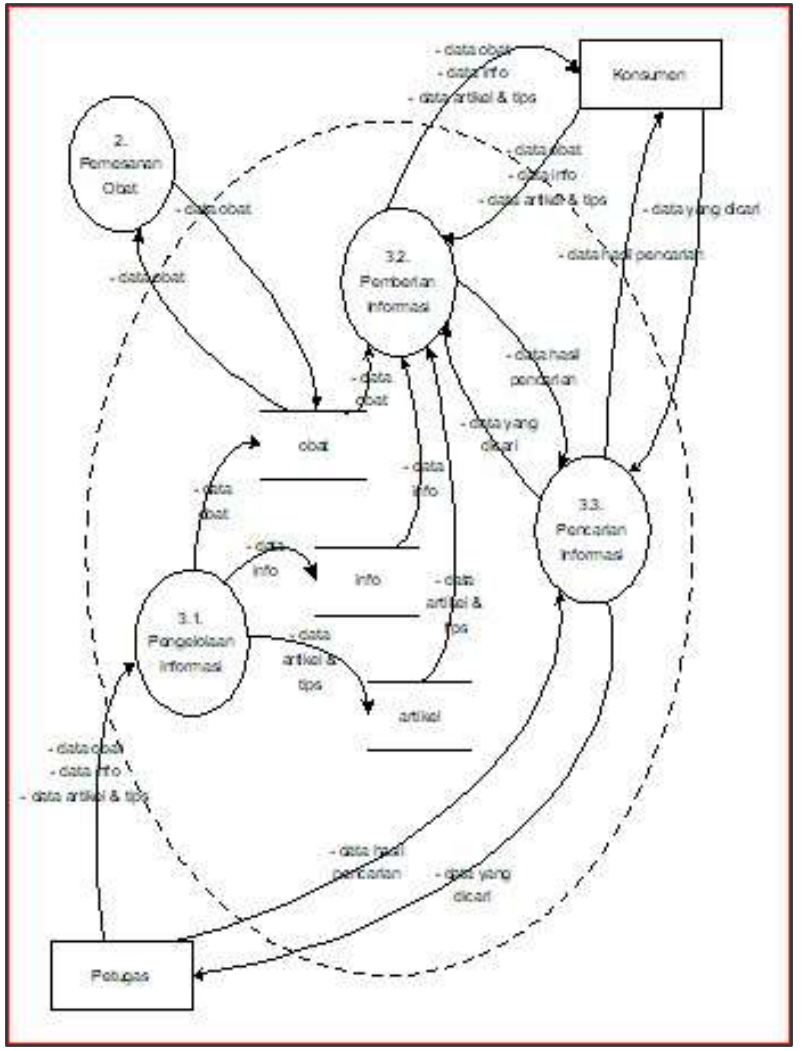


Gambar 6. DFD Level 1 Prosedur Pelayanan Informasi (Analisis Sistem).

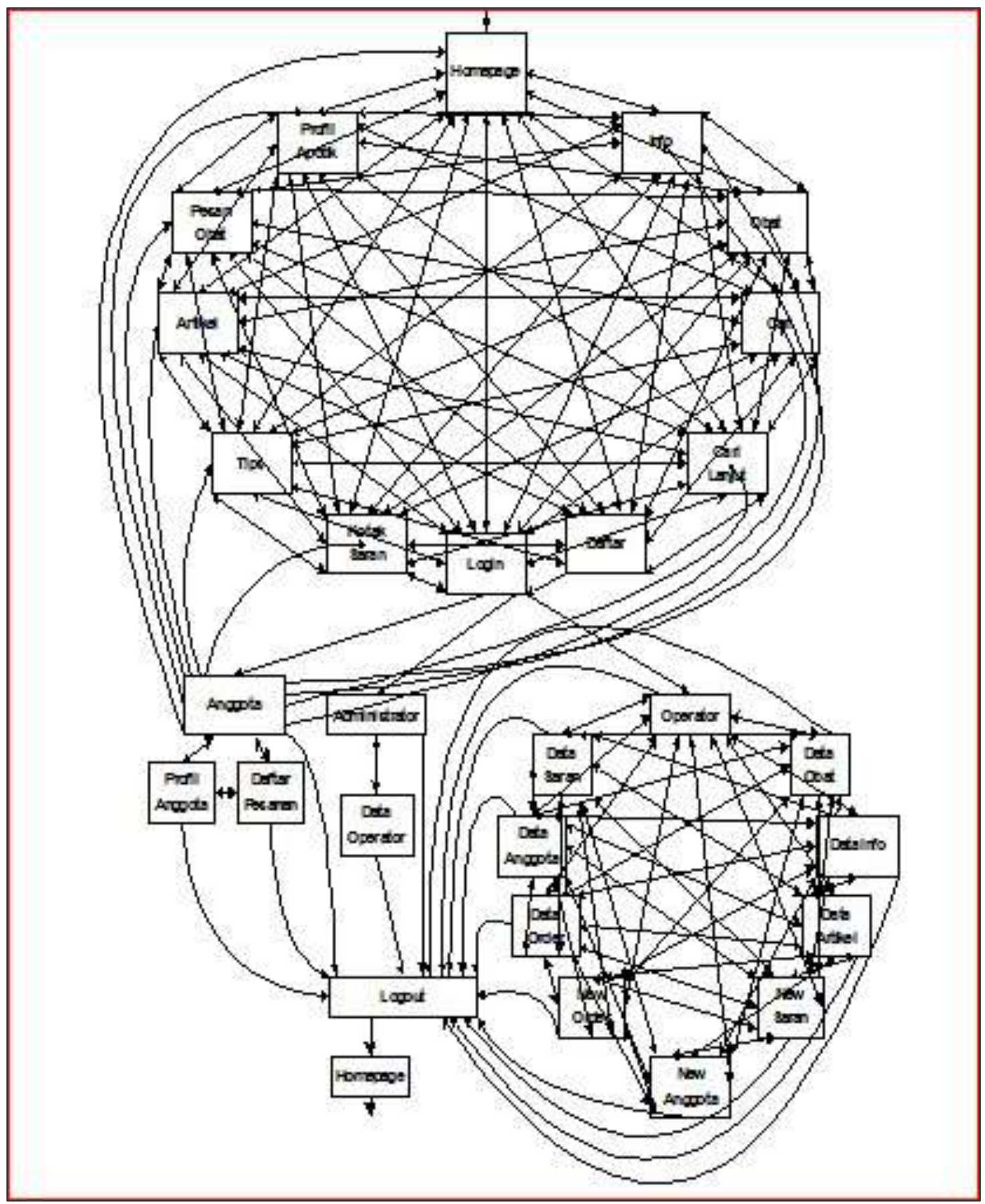

Gambar 7. Struktur Link. 
Uji coba perangkat lunak ini dilakukan pada setiap prosedur yang ada. Dibawah ini dapat dilihat tampilan utama web, dan untuk lebih jelasnya mengenai uji coba perangkat lunak dapat dilihat pada tabel tampilan prosedur.
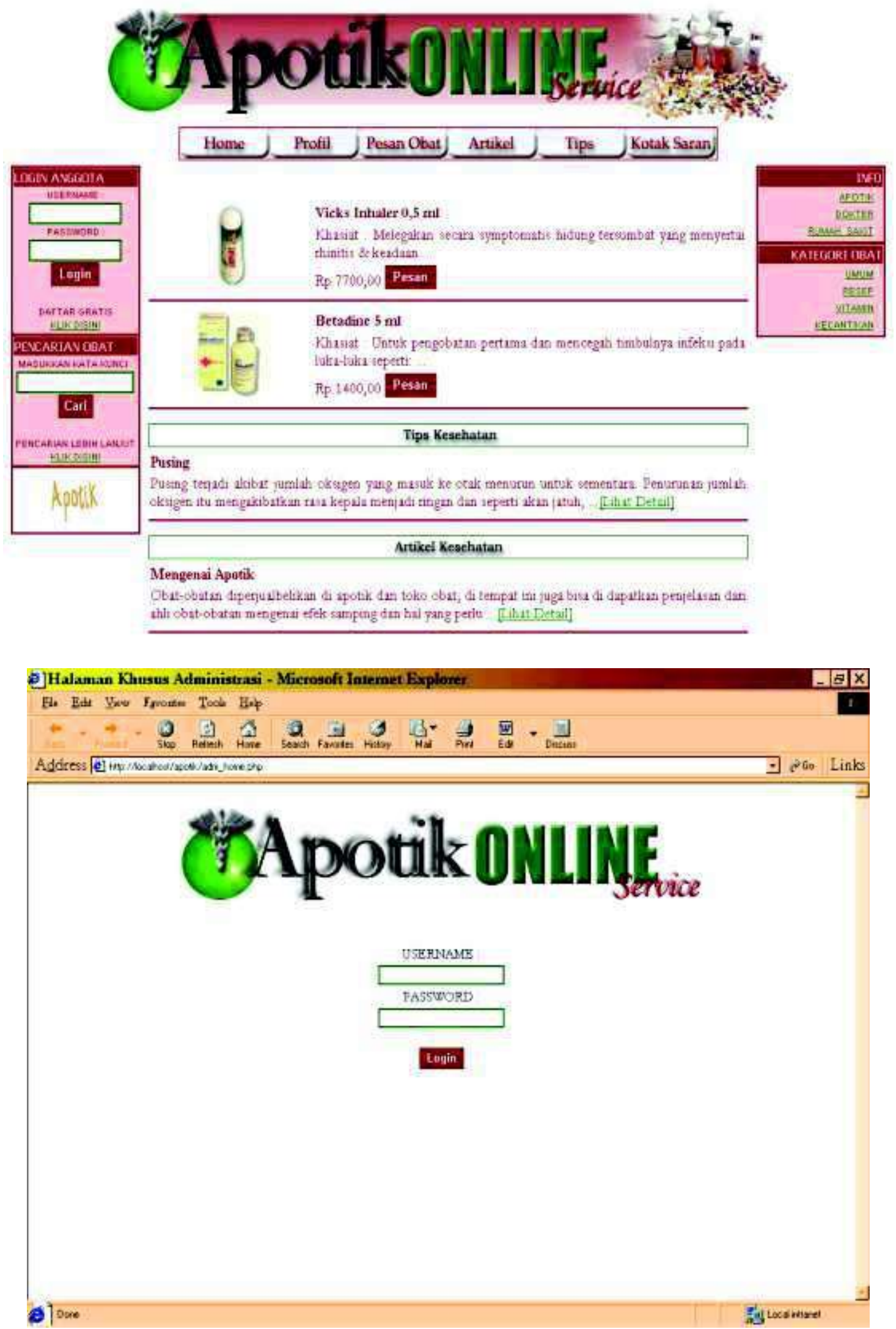
Gambar 8. Tampilan Halaman Utama.

Tampilan Prosedur Daftar.

\begin{tabular}{|c|c|c|c|}
\hline No. & \multicolumn{3}{|c|}{ Tampilan dan Keterangan } \\
\hline \multirow[t]{4}{*}{1.} & \multicolumn{3}{|c|}{ PENDAFTARAN ANGGOTA BARU } \\
\hline & \multirow[t]{2}{*}{ E-Mail } & tesa@mail.com & \\
\hline & & Submit & \\
\hline & \multicolumn{3}{|c|}{ Tampilan form isi e-mail dan cek e-mail } \\
\hline
\end{tabular}




\begin{tabular}{|l|l|l|}
\hline 2. & PENDAFTARAN ANGGOTA BARU \\
\hline tesa@mail.com & \\
Username & Subst. SELAMAT SIANG \\
& \\
Tampilan form isi username dan cek username
\end{tabular}

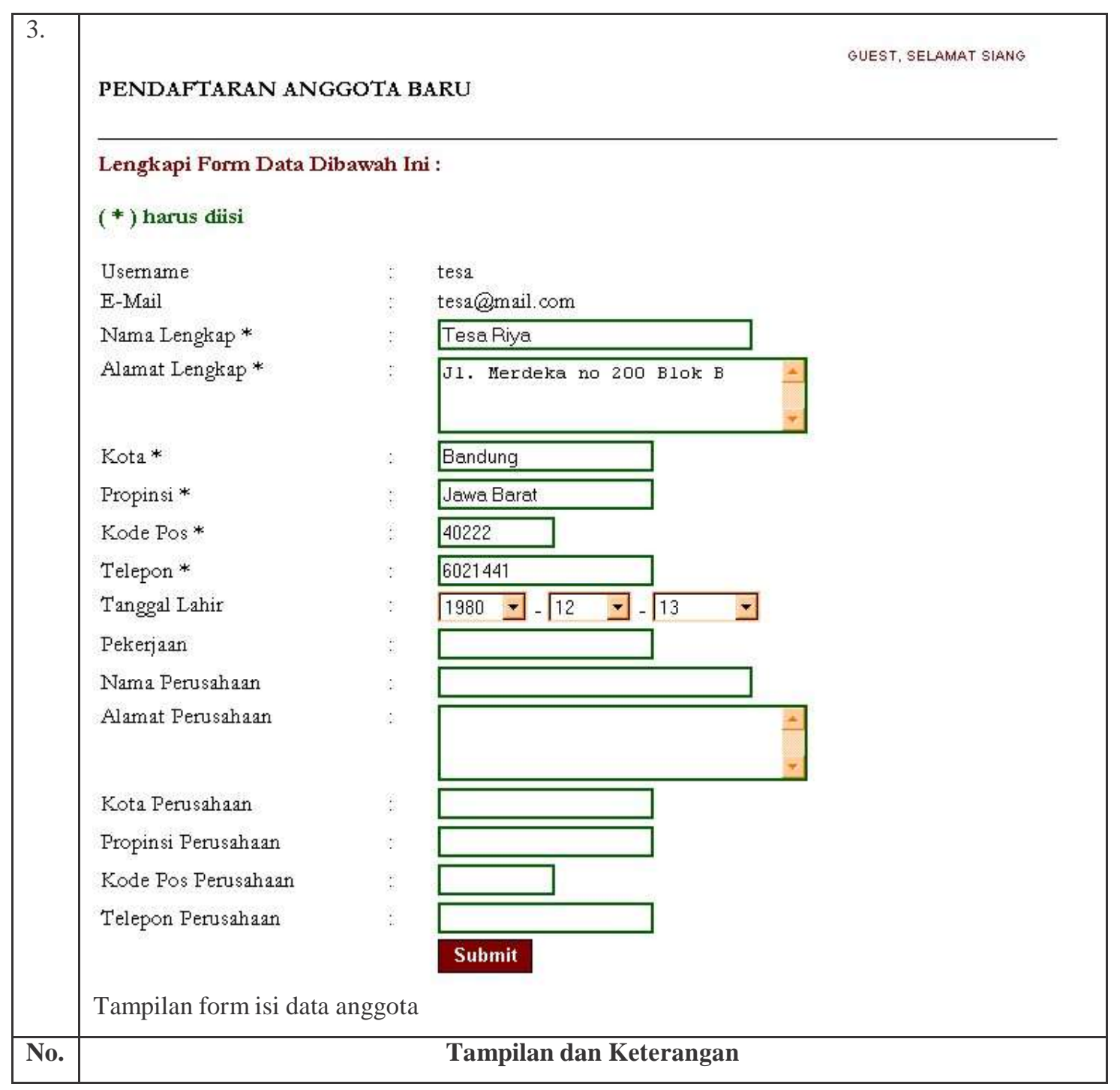




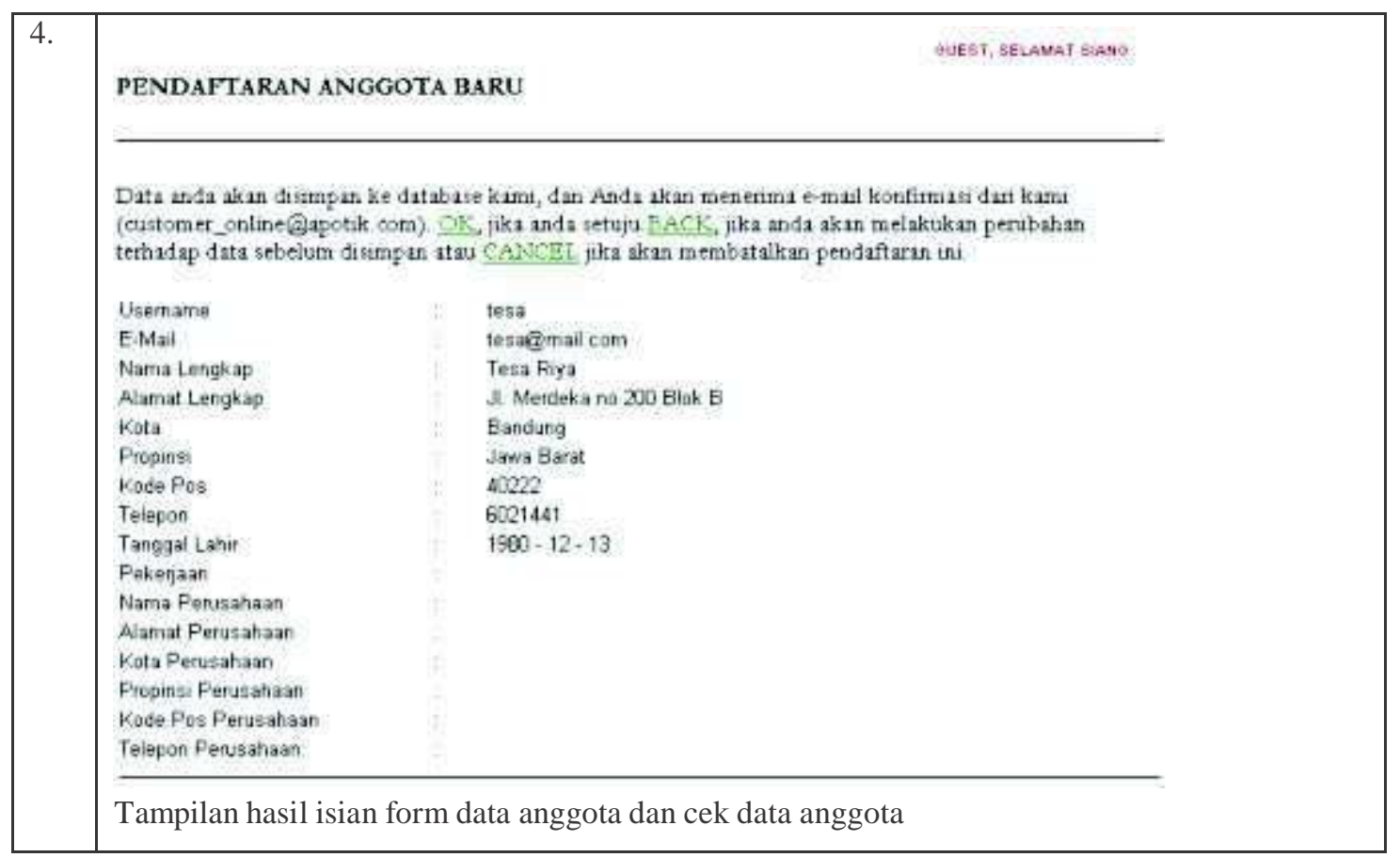

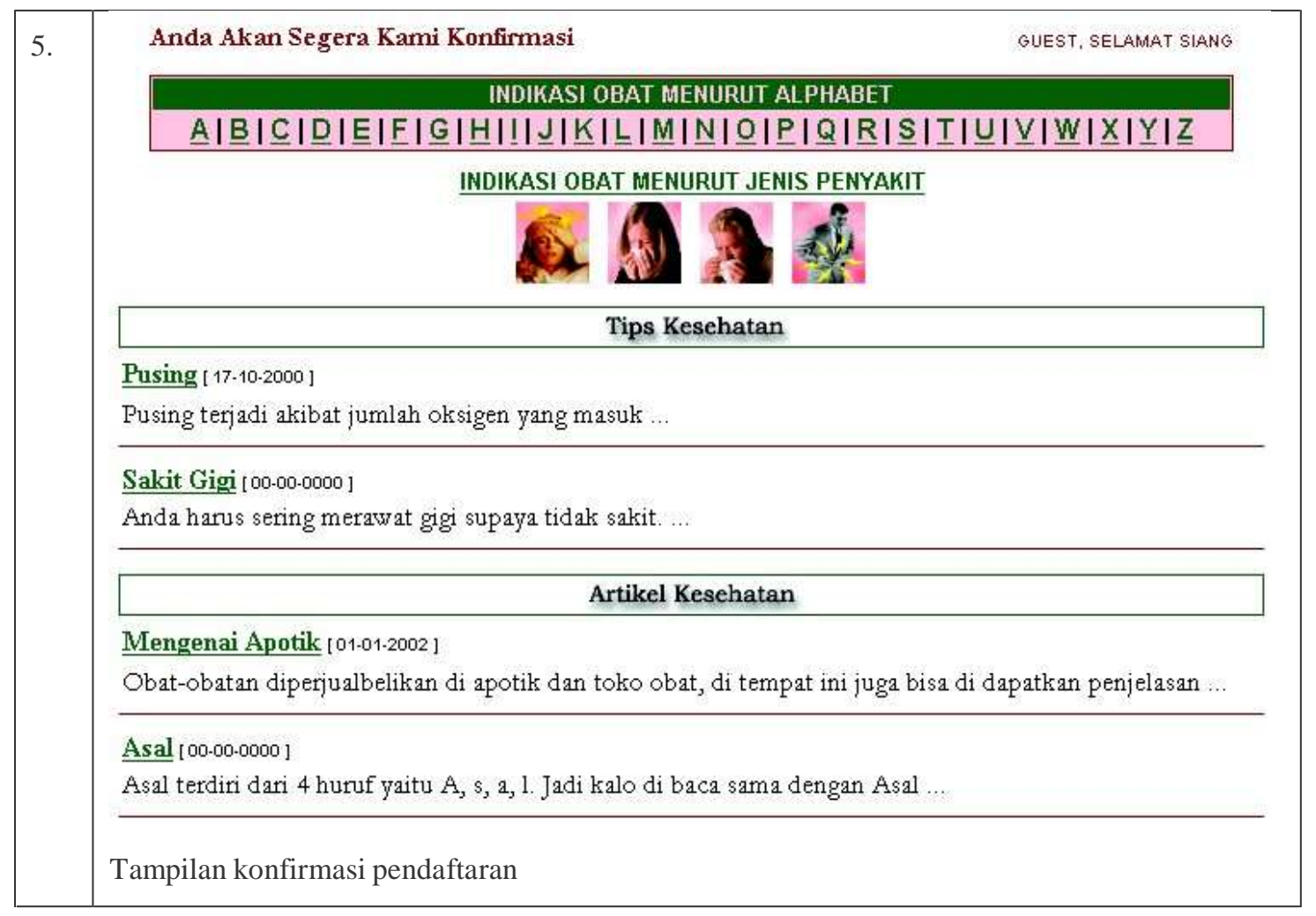


Tampilan Prosedur Login.

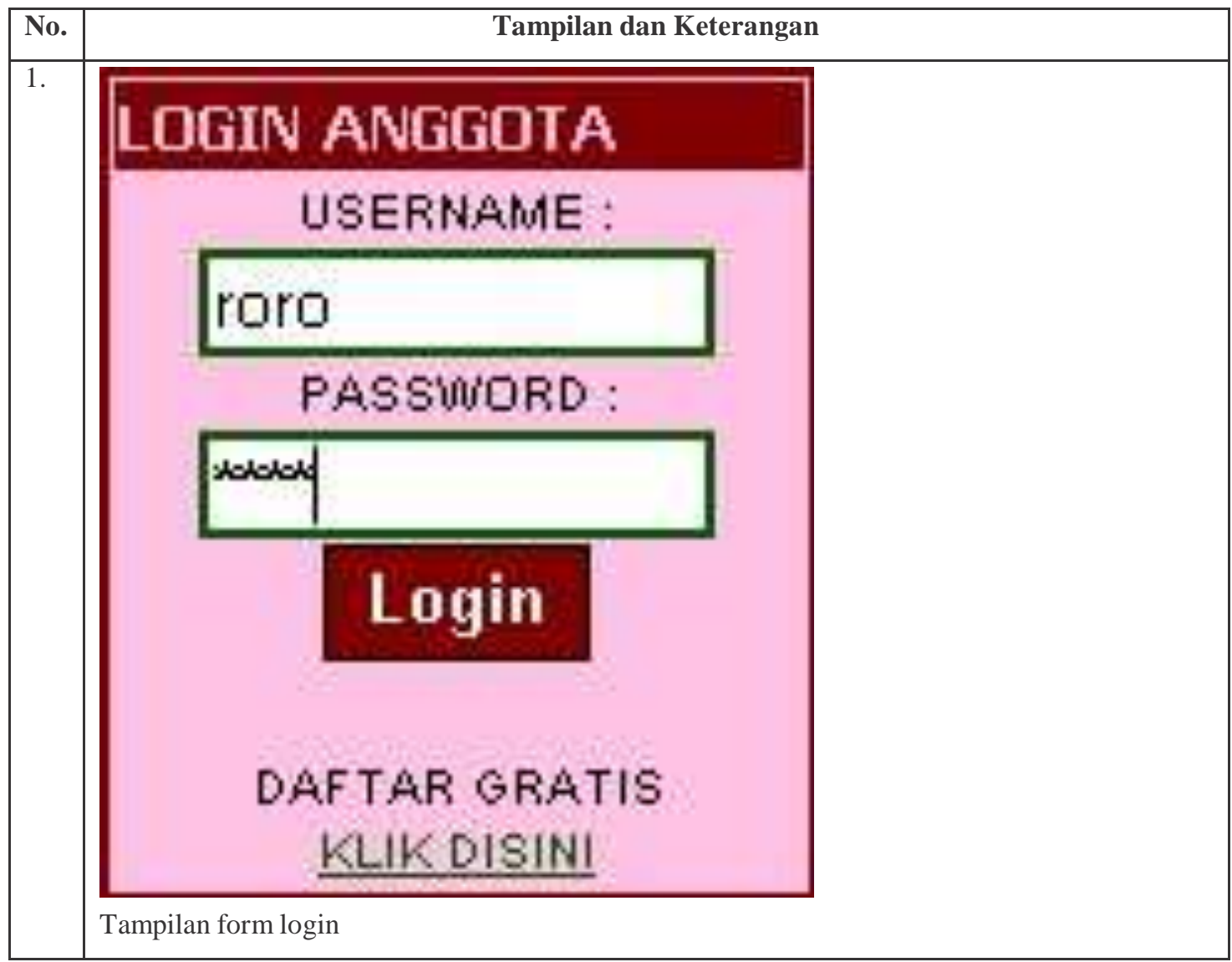

No.

Tampilan dan Keterangan 


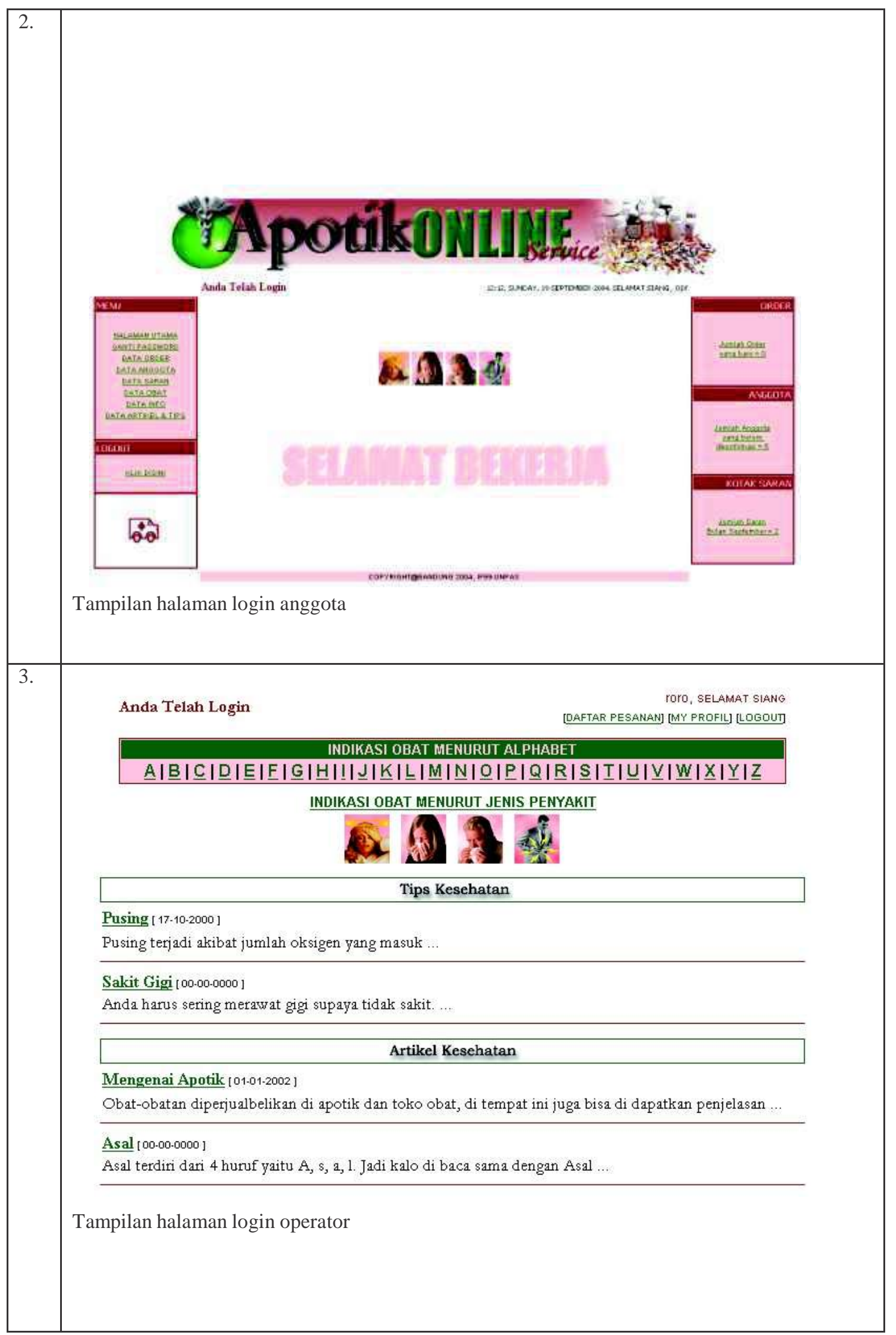




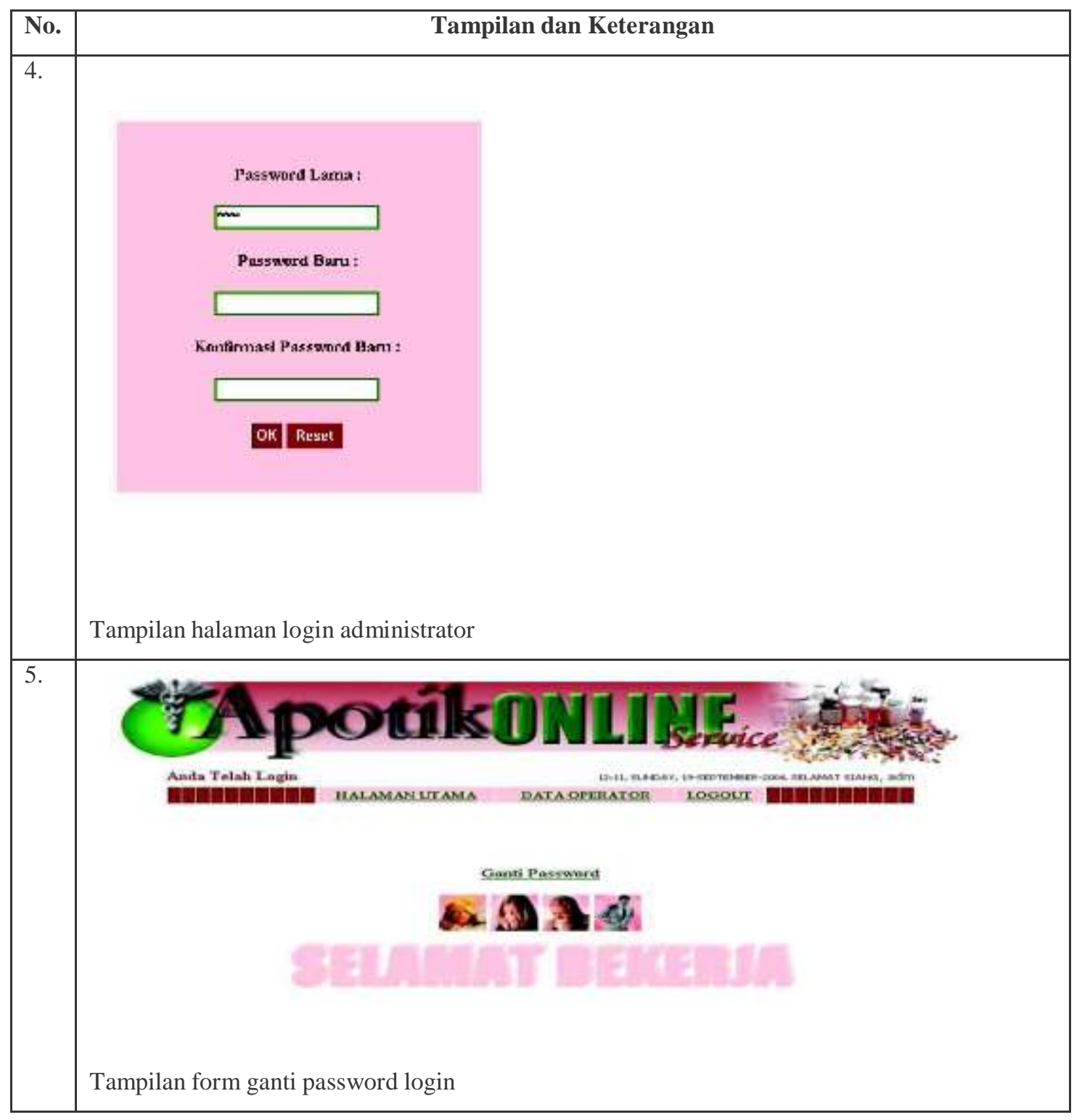

Tampilan Prosedur Pesan.

\begin{tabular}{|c|c|}
\hline No. & Tampilan dan Keterangan \\
\hline 1. & $\begin{array}{l}\text { 2. Daktarin } 5 \text { gram } \\
\text { Khasiat: Untuk penyahit kulit yang diakibattirn oleh jamur, seprti panu, } \\
\text { penyahit... } \\
\text { Rp. } 17000,00 \\
10 \text { Pesan }\end{array}$ \\
\hline & Tampilan form input item pesan, dan cek status anggota beserta cek data obat \\
\hline
\end{tabular}




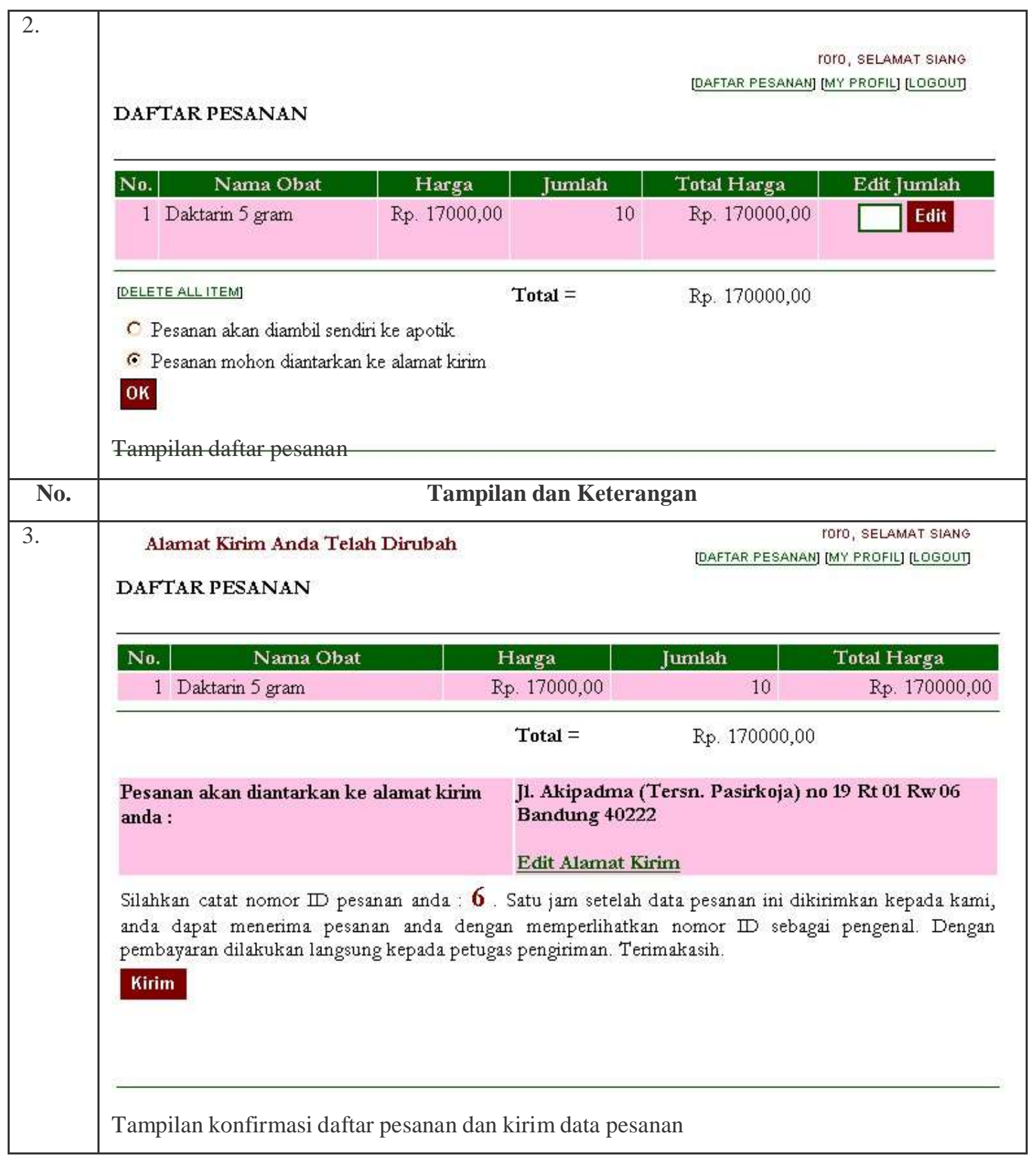

Tampilan Prosedur Cari Data.

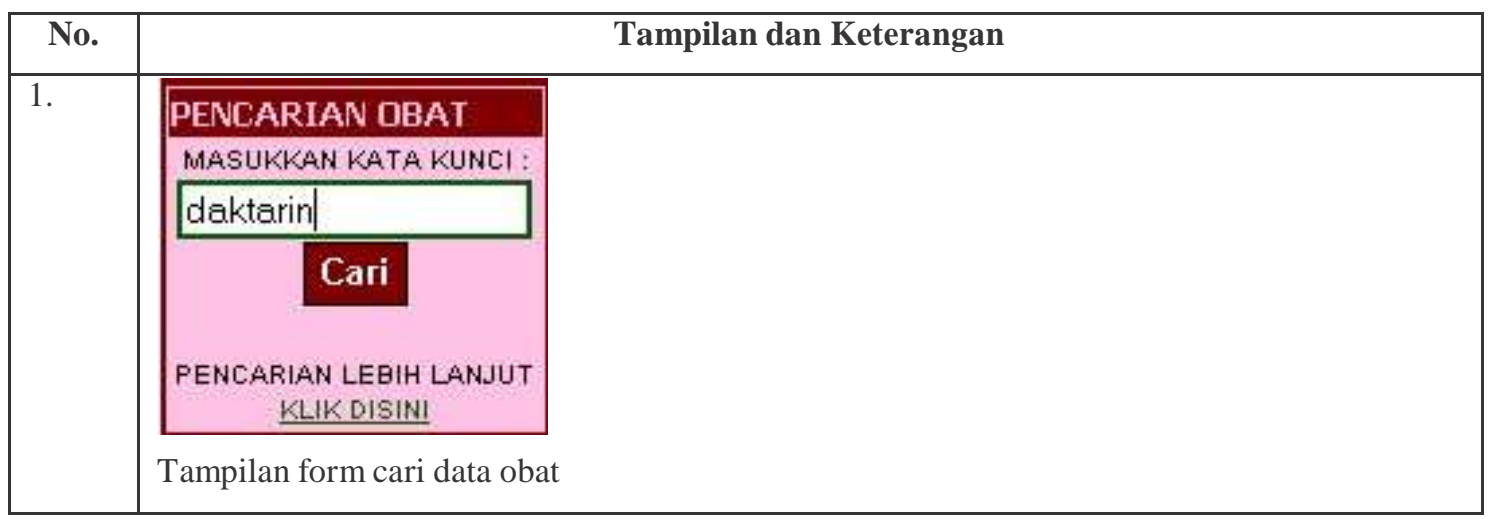




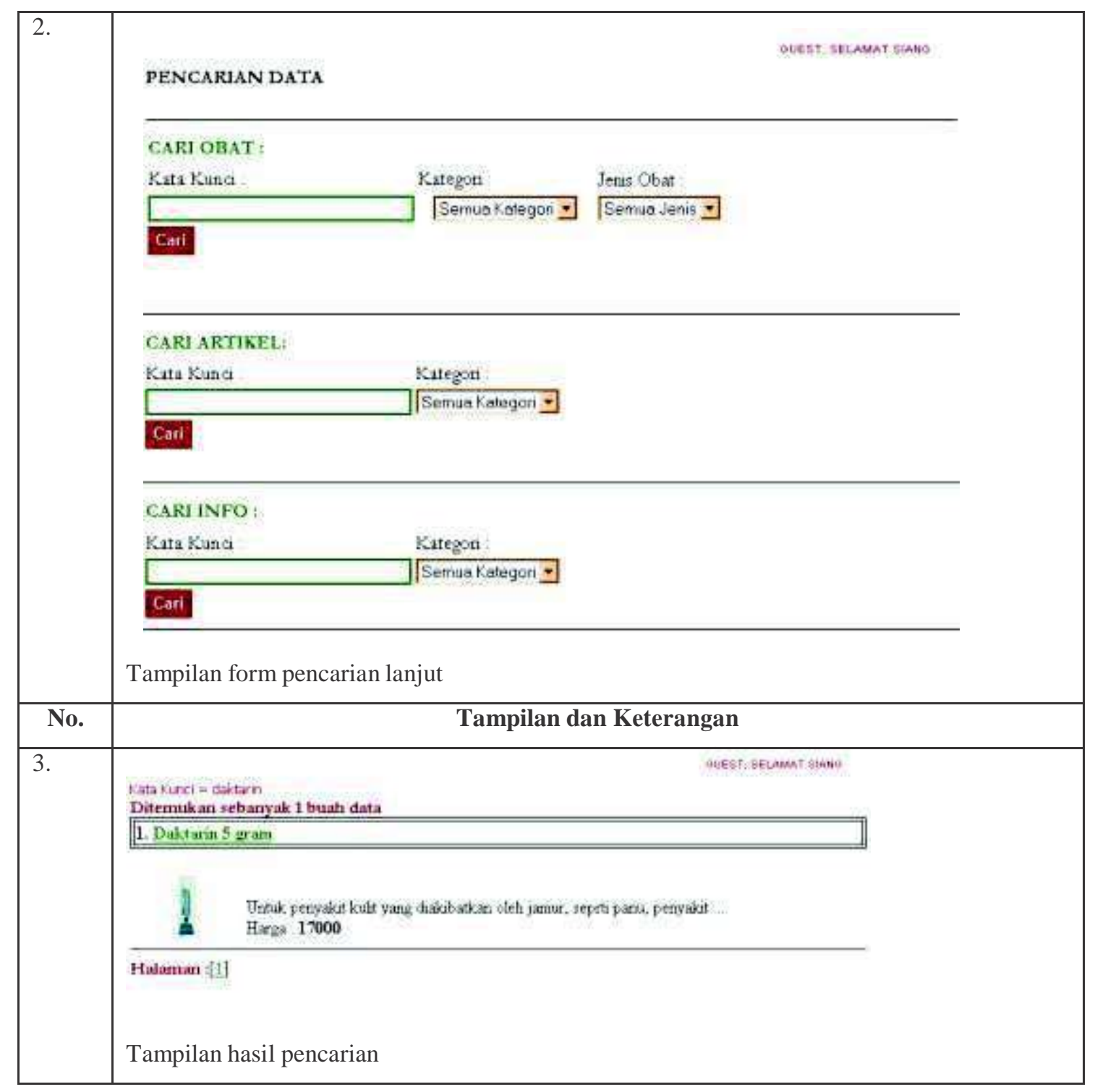

Tampilan Prosedur Isi Saran.

No.

Tampilan dan Keterangan 


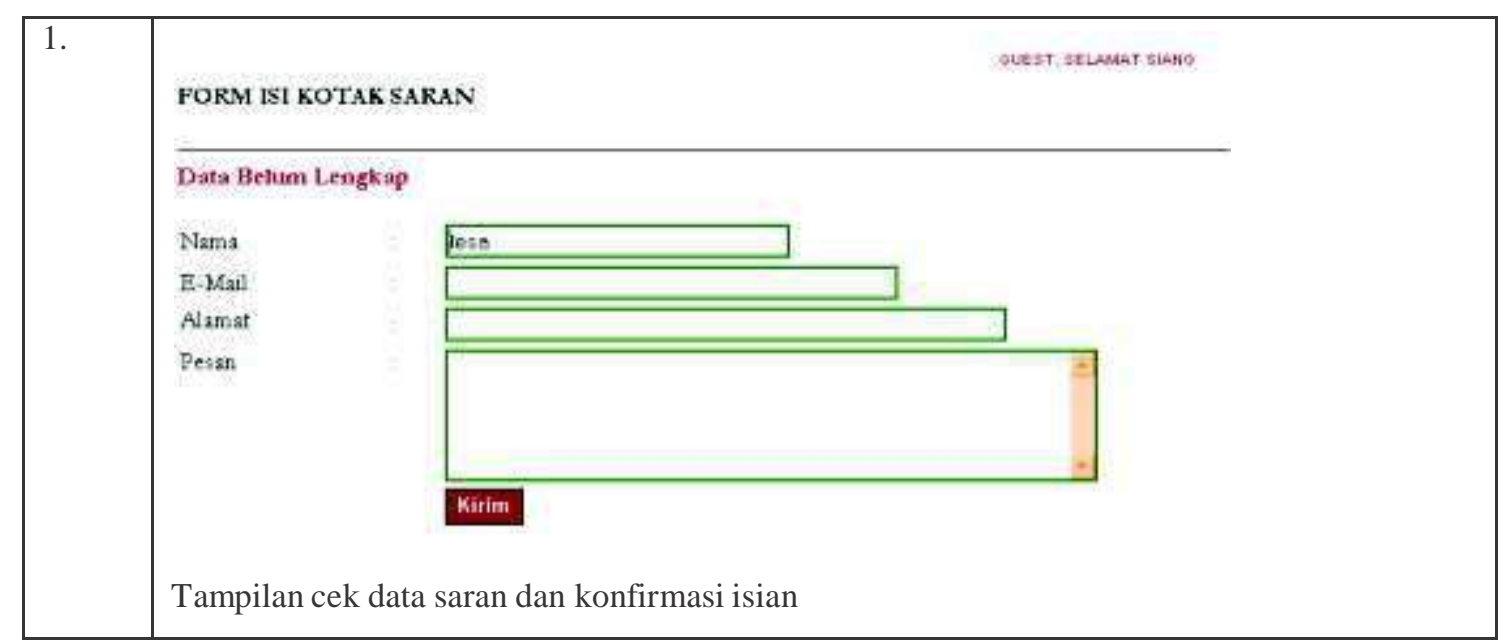

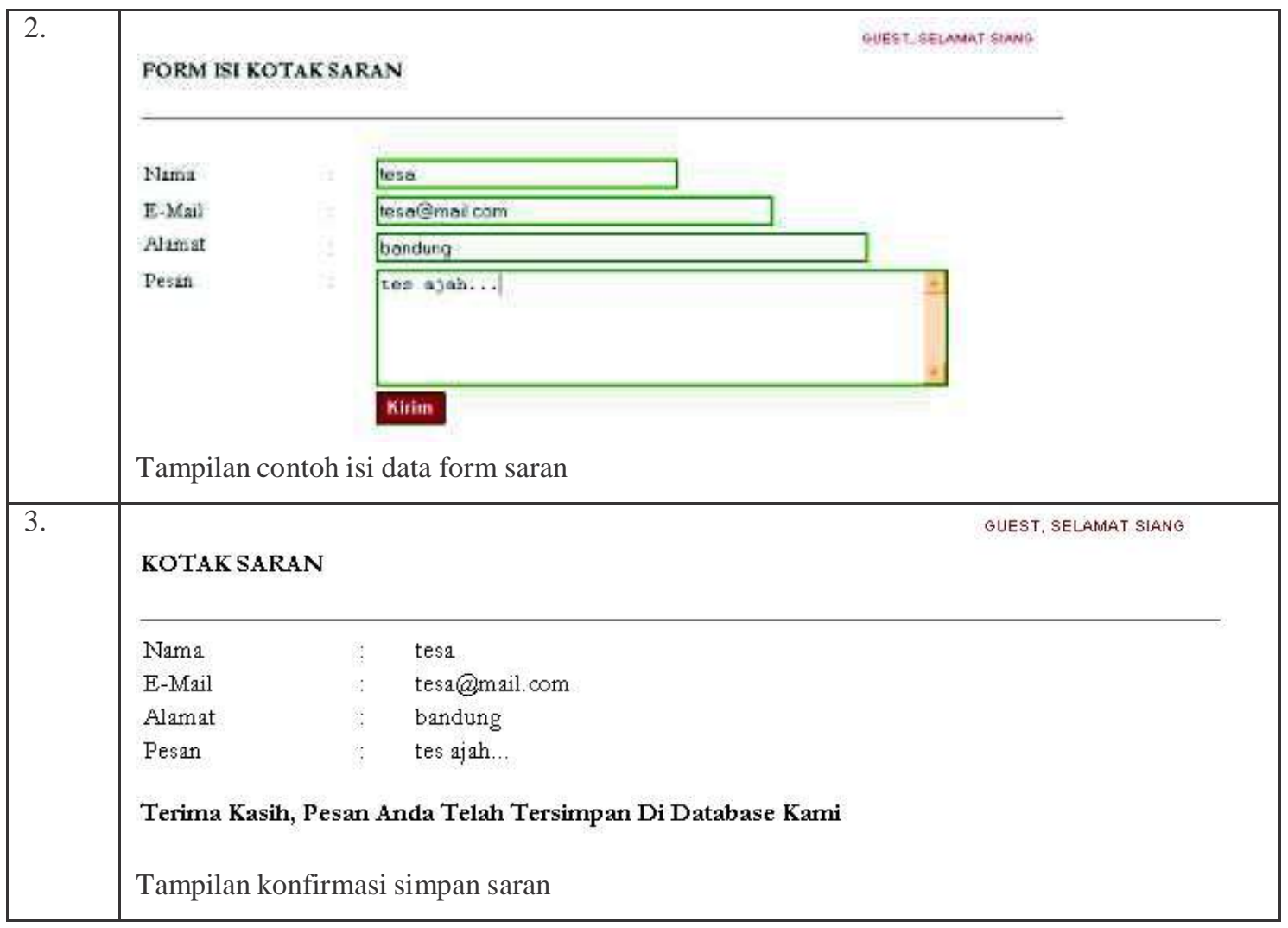

Tampilan Prosedur Pengelolaan Data.

No.

Tampilan dan Keterangan 


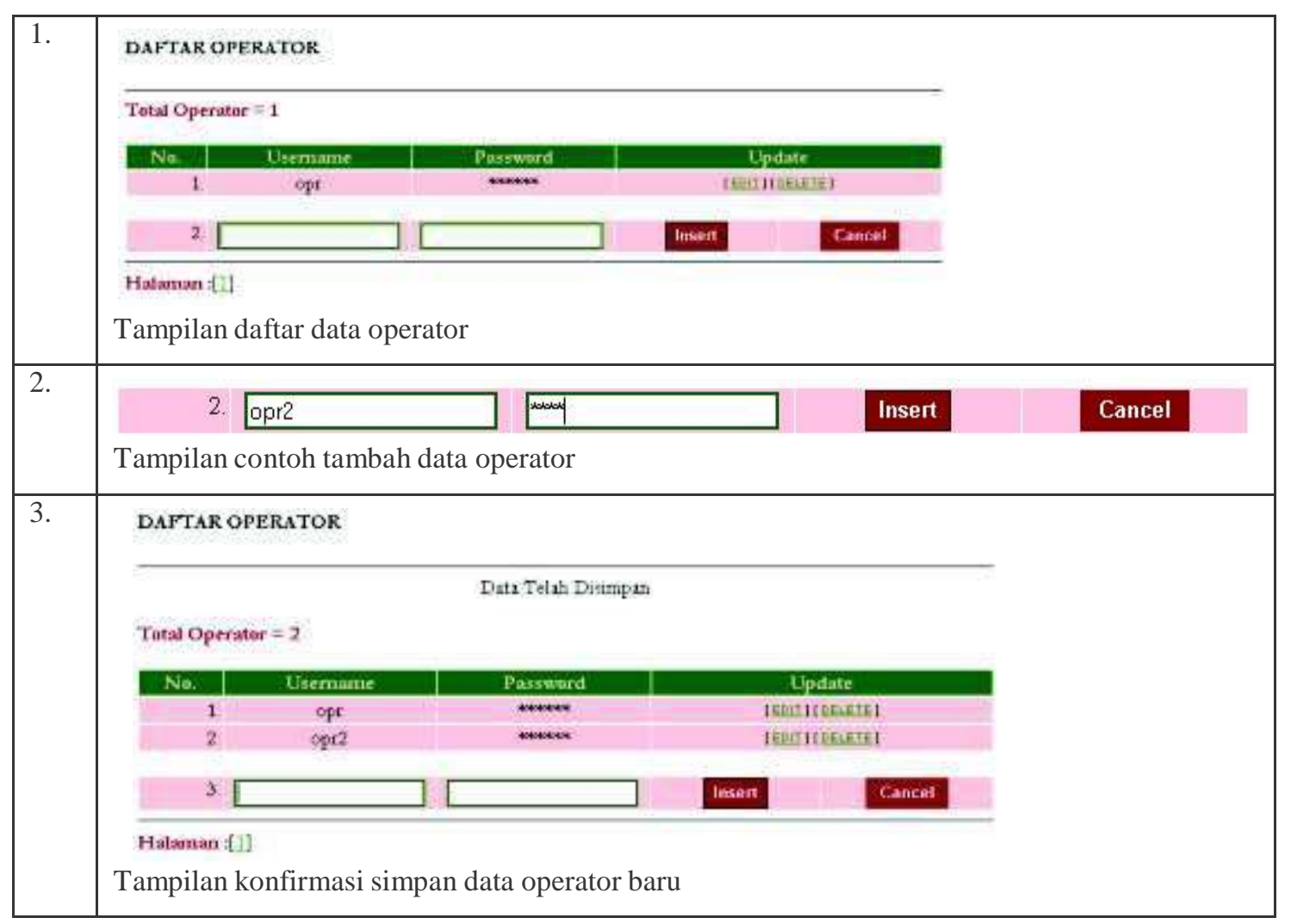

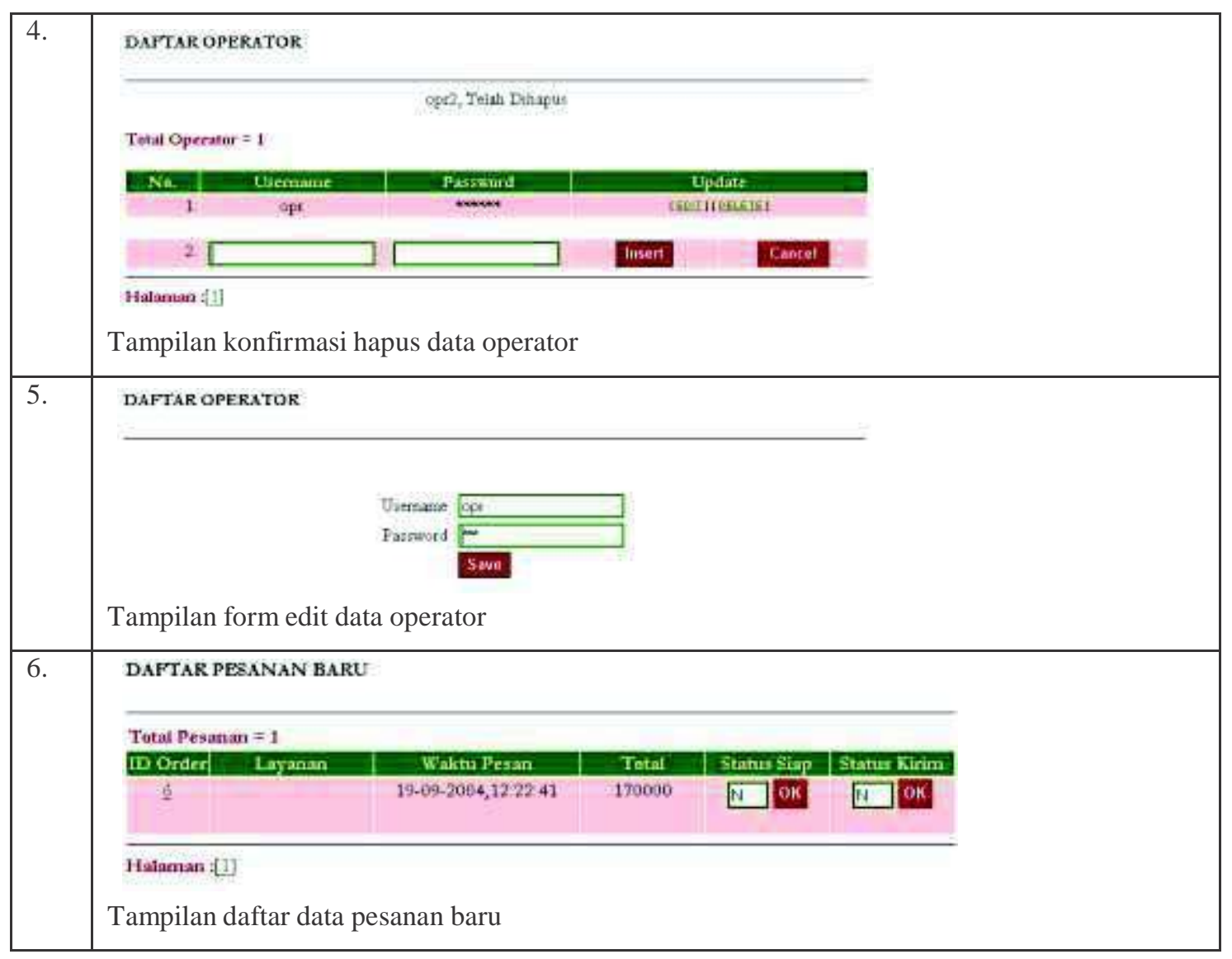




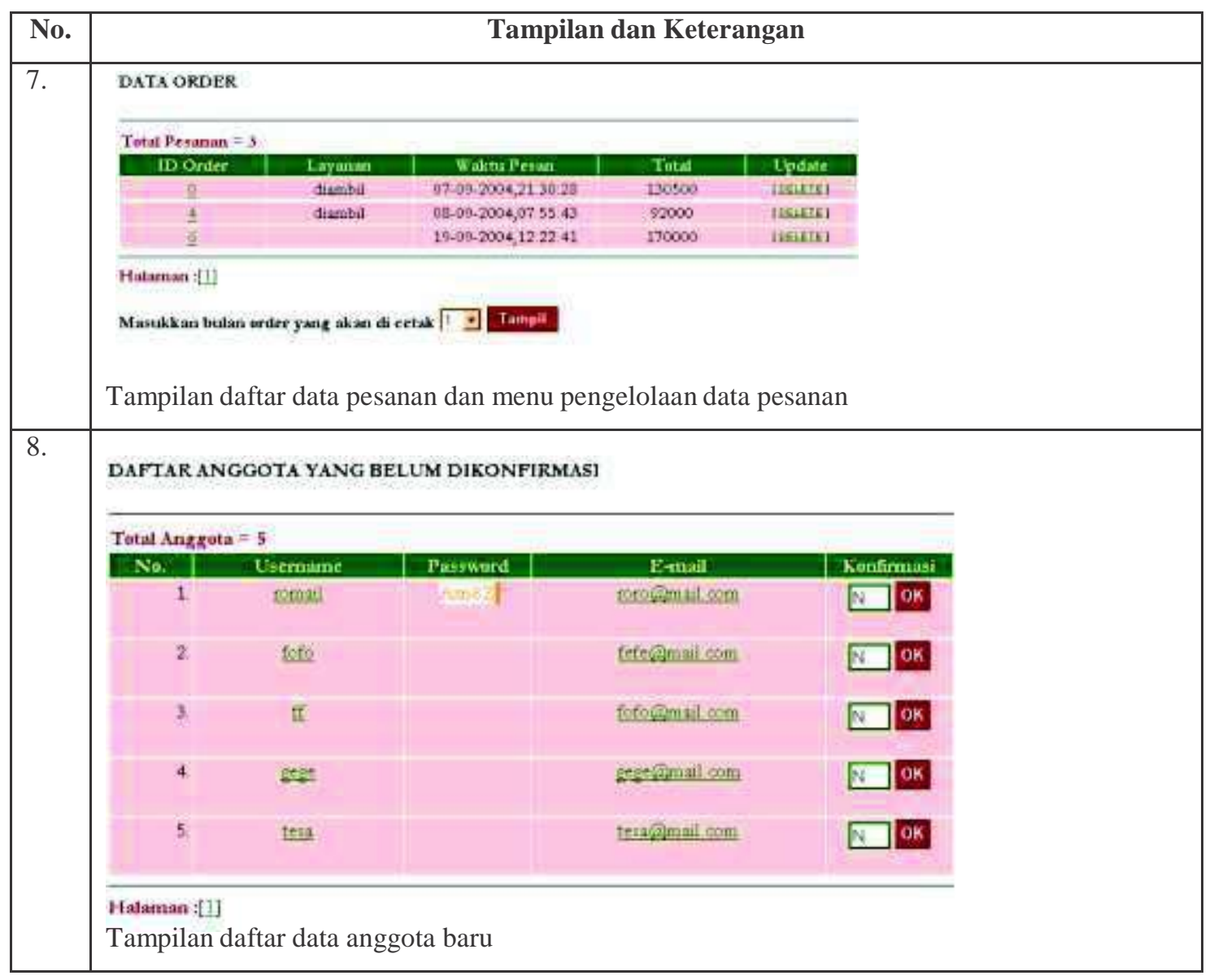

\begin{tabular}{|c|c|c|c|c|c|}
\hline \multirow[t]{14}{*}{9.} & \multicolumn{5}{|c|}{ DATA ANGGOTA } \\
\hline & \multicolumn{5}{|c|}{ Total Anggota $=9$} \\
\hline & No. & Username & E-mail & Last Login & Update \\
\hline & 1. & $\underline{\text { roto }}$ & Santi@W/artech.com & $\begin{array}{c}2004-09-19 \\
12: 24: 29\end{array}$ & [EDIT] [DELETE] \\
\hline & 2. & $\underline{\text { fefe }}$ & fefe@yahoo.com & $\begin{array}{c}0000-00-00 \\
00: 00: 00\end{array}$ & [EDIT] [DELETE] \\
\hline & 3. & romail & roro@mail.com & $\begin{array}{c}0000-00-00 \\
00: 00: 00\end{array}$ & [EDIT] [DELETE] \\
\hline & 4. & $\underline{\text { leony }}$ & leony@mail.com & $\begin{array}{c}0000-00-00 \\
00: 00: 00\end{array}$ & [EDIT] [DELETE] \\
\hline & 5. & tes & tes@tes.com & $\begin{array}{c}0000-00-00 \\
00: 00: 00\end{array}$ & [EDIT] [DELETE] \\
\hline & 6. & $\underline{\text { fofo }}$ & fefe@mail.com & $\begin{array}{c}0000-00-00 \\
00: 00: 00\end{array}$ & [EDIT] [DELETE] \\
\hline & 7. & $\underline{\mathrm{ff}}$ & fofo@mail.com & $\begin{array}{c}0000-00-00 \\
00: 00: 00\end{array}$ & [EDIT] [DELETE] \\
\hline & 8. & $\underline{\text { tesa }}$ & tesa@mail.com & $\begin{array}{c}0000-00-00 \\
00: 00: 00\end{array}$ & [EDIT] [DELETE] \\
\hline & 9. & gege & gege@mail.com & $\begin{array}{c}0000-00-00 \\
00: 00: 00\end{array}$ & [EDIT] [DELETE] \\
\hline & \multicolumn{5}{|c|}{ Halaman :[1] } \\
\hline & \multicolumn{5}{|c|}{ Tampilan daftar data anggota dan menu pengelolaan data anggota } \\
\hline
\end{tabular}




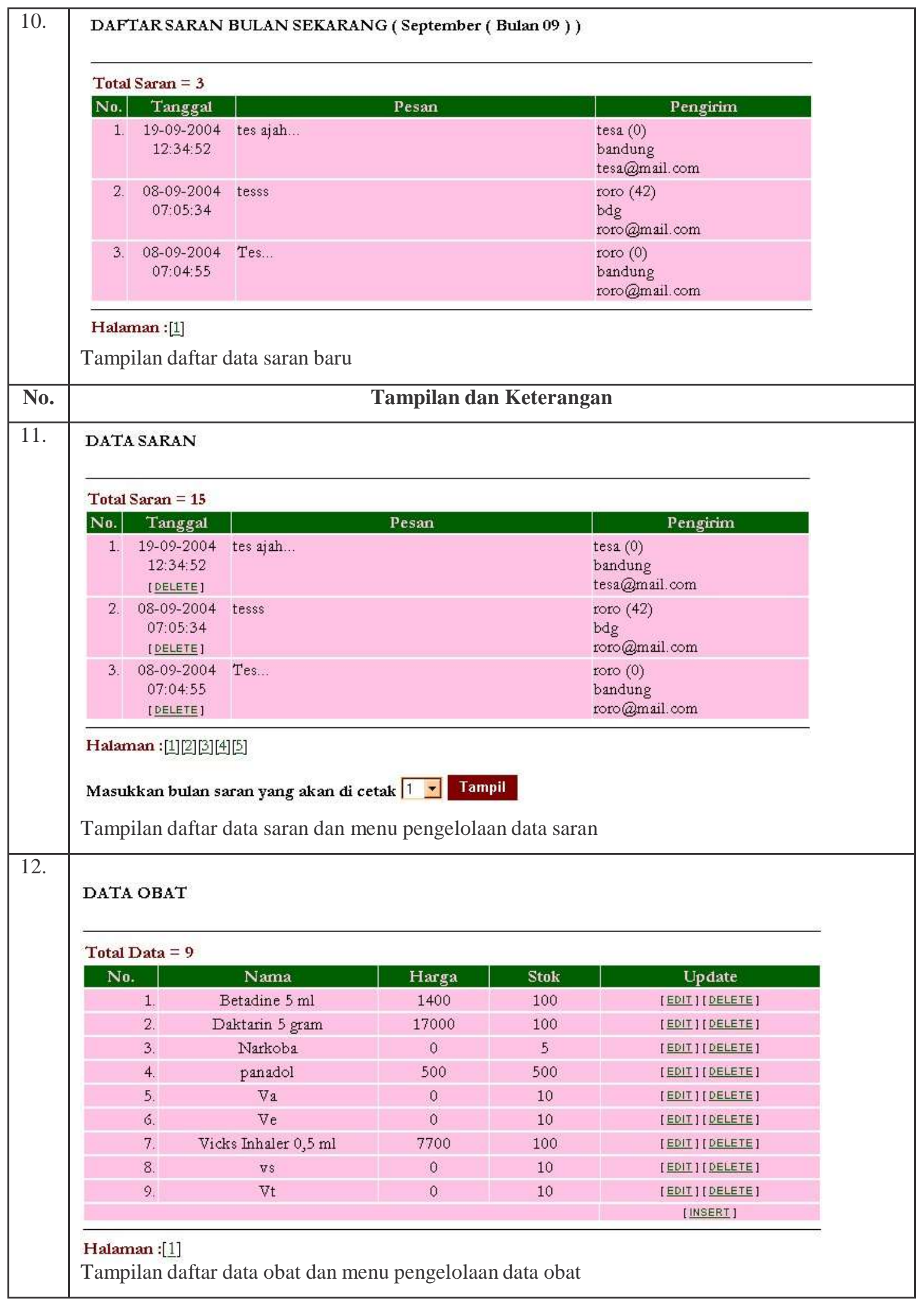




\begin{tabular}{|c|c|c|c|c|c|c|}
\hline \multirow[t]{9}{*}{13.} & \multicolumn{6}{|c|}{ DATA INFO } \\
\hline & \multicolumn{6}{|c|}{ Total Info $=3$} \\
\hline & No. & Kategori & Nama & Alamat & Keterangan & Update \\
\hline & 1. & Apotik & $\begin{array}{l}\text { Apotik Kimia } \\
\text { Farma } 9\end{array}$ & $\begin{array}{c}\text { J1. Asia Afrika No.9. } \\
\text { Telepon : } 434291\end{array}$ & $\begin{array}{l}\text { Apotik } 24 \text { jam di } \\
\text { Bandung }\end{array}$ & [EDIT] [DELETE] \\
\hline & 2. & Dokter & Dr. Dimyati & $\begin{array}{l}\text { J1. Pasir Kaliki. } \\
\text { Telepon :- }\end{array}$ & $\begin{array}{l}\text { Spesialis Bedah } \\
\text { Tumor }\end{array}$ & [EDIT] [ DELETE] \\
\hline & 3. & Rumah Sakit & $\begin{array}{l}\text { Rumah Sakit } \\
\text { Hasan Sadikin }\end{array}$ & $\begin{array}{l}\text { Bandung. Telepon: } \\
022\end{array}$ & - & [EDIT] [ DELETE] \\
\hline & & & & & & [INSERT] \\
\hline & Halaman & & & & & \\
\hline & Tampilan & daftar data ir & fo dan menu & pengelolaan data & info & \\
\hline \multirow[t]{12}{*}{14.} & \multicolumn{6}{|c|}{ DATA ARTIKEL \& TIPS KESEHATAN } \\
\hline & \multicolumn{6}{|c|}{ Total Data $=6$} \\
\hline & \begin{tabular}{|l|l} 
No. & \\
\end{tabular} & Kategori & & JuduI & & Update \\
\hline & 1. & Artikel & & Mengenai Apoti & & [EDIT] [ [DELETE] \\
\hline & 2. & Artikel & & Asal & & [EDIT][DELETE] \\
\hline & 3. & Artikel & & Coklat & & [EDIT] [ DELETE] \\
\hline & 4. & Artikel & & $\underline{\text { Keju }}$ & & [EDIT] [DELETE] \\
\hline & 5. & Tips & & Pusing & & [EDIT] [ DELETE] \\
\hline & 6. & Tips & & Sakit Gigi & & [EDIT] [DELETE] \\
\hline & & & & & & [INSERT] \\
\hline & \multicolumn{6}{|c|}{ Halaman :[1] } \\
\hline & \multicolumn{6}{|c|}{ Tampilan daftar data artikel dan menu pengelolaan data artikel } \\
\hline
\end{tabular}

\section{Kesimpulan}

Kesimpulan dari hasil perancangan prototype dan hasil analisis, yaitu :

a. Sistem pelayanan yang dirancang merupakan sistem pelayanan yang cocok untuk apotik yang berdiri sendiri tanpa terkait divisi-divisi seperti dirumah sakit, dan bermaksud untuk memperluas konsumen yang tidak terbatas waktu dan terbatas tempat melalui internet, dengan sistem pesanan secara delivery.

b. Sistem yang dibangun dapat membantu pihak apotik dalam melakukan manajemen penyimpanan data obat, membantu proses penjualan yaitu pada pemesan obat dan dapat menjadi media informasi pada menu pencarian data terhadap data tertentu yaitu data obat, data info, artikel dan tips kesehatan.

Rekomendasi untuk penerapan dan penelitian selanjutnya adalah :

a. Menerima pembayaran melalui web.

b. Melakukan pengelolan keuangan untuk pihak apotik, sehingga diperoleh laporan hasil penjualan dan labanya.

c. Menerima login dari apotik untuk input data obat dan lokasinya sehingga menjadi cabang terdekat untuk bisa dihubungi konsumen, dan login dokter untuk input data obat resep.

d. Pengembangan aplikasi berbasis android.

\section{Daftar pustaka}

[1] Tharom,Tabratas, 2002. Dinata,Marta, Xerandy, "Mengenal Teknologi Informasi", 
Elex Media Komputindo, Jakarta.

[2] Indrajit, Richardus Eko, Prastowo, Bambang N, Muttaqin, Haris, Abdullah. 2002. "Membangun Aplikasi e-Government", Elex Media Komputindo, Jakarta.

[3] Maidiansyah, Dendy, Suwandi, Hassan, ukhlis, Aris, Muma, Gaos. 2002. "Sistem Informasi Pengelolaan Stock Obat di Apotik Cicalengka". Laporan Presentasi Sistem Informasi. Teknik Informatika Unpas Bandung.

[4] Tempo, April 2004. “Tempointeraktif.com-PP RI No. 25 Tahun 1980”, Juni 2004, http://www.tempo.co.id/hg/peraturan/2004/04/12/prn,20040412-05,id.html.

[5] Pressman, Roger S, 2001. "Software Engineering". 